Keeping the Peace in the Cyprus Crisis of 1963-64 
Also by Alan James

THE POLITICS OF PEACEKEEPING

THE BASES OF INTERNATIONAL ORDER. Essays in Honour of C.A.W. Manning (editor)

SOVEREIGN STATEHOOD: The Basis of International Society

* PEACEKEEPING IN INTERNATIONAL POLITICS

STATES IN A CHANGING WORLD (co-editor with Robert H. Jackson)

* BRITAIN AND THE CONGO CRISIS, 1960-63

* A DICTIONARY OF DIPLOMACY (with G. R. Berridge)

* From the same publishers 


\section{Keeping the Peace in the Cyprus Crisis of 1963-64}

Alan James

Professor Emeritus

Keele University 


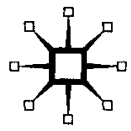

(C) Alan James 2002

Reprint of the original edition 2002

All rights reserved. No reproduction, copy or transmission of this publication may be made without written permission.

No paragraph of this publication may be reproduced, copied or transmitted save with written permission or in accordance with the provisions of the Copyright, Designs and Patents Act 1988, or under the terms of any licence permitting limited copying issued by the Copyright Licensing Agency, 90 Tottenham Court Road, London W1T 4LP.

Any person who does any unauthorised act in relation to this publication may be liable to criminal prosecution and civil claims for damages.

The author has asserted his right to be identified as the author of this work in accordance with the Copyright, Designs and Patents Act 1988.

First published 2002 by

PALGRAVE

Houndmills, Basingstoke, Hampshire RG21 6XS and

175 Fifth Avenue, New York, N. Y. 10010

Companies and representatives throughout the world

PALGRAVE is the new global academic imprint of St. Martin's Press LLC Scholarly and Reference Division and Palgrave Publishers Ltd (formerly Macmillan Press Ltd).

ISBN 978-1-349-41141-2 ISBN 978-1-4039-0089-0 (eBook) DOI 10.1057/9781403900890

This book is printed on paper suitable for recycling and made from fully managed and sustained forest sources.

A catalogue record for this book is available from the British Library.

Library of Congress Cataloging-in-Publication Data James, Alan, 1933-

Keeping the peace in the Cyprus Crisis of 1963-64 / Alan James. p. $\mathrm{cm}$.

Includes bibliographical references and index. ISBN 978-0-333-74857-2

1. Cyprus-History-Cyprus Crisis, 1963-Peace. 2. United Nations-Peacekeeping forces-Cyprus-History-20th century. 3. Peacekeeping forces-Great Britain-History-20th century. 4. Peacekeeping forces-Cyprus-History-20th century. I. Title.

DS54.9.J36 2001

$956.9304-\mathrm{dc} 21$

$\begin{array}{llllllllll}10 & 9 & 8 & 7 & 6 & 5 & 4 & 3 & 2 & 1\end{array}$

$\begin{array}{llllllllll}11 & 10 & 09 & 08 & 07 & 06 & 05 & 04 & 03 & 02\end{array}$ 
To Lorna 


\section{Contents}

List of Maps viii

Acknowledgements ix

Chronology xii

Leading Personalities $\quad \mathrm{xV}$

Terminology, Sources and Abbreviations xvii

Part I Prelude 1

1 Problem 3

2 Settlement $\quad 12$

3 Collapse 29

Part II The Crisis $\quad 39$

4 The West's Interest in a Peaceful Cyprus 41

5 Containing the Crisis: I The British Period 59

6 Britain's Search for Partners: I Nato 76

7 Britain's Search for Partners: II The UN 87

8 Recruiting the UN Force 100

9 Organizing the UN Force 117

10 The Operational Methods of the UN Force 128

11 Containing the Crisis: II The UN Period 138

12 The Quest for a Better Settlement 159

13 Postscript 170

$\begin{array}{ll}\text { Notes } & 175\end{array}$

$\begin{array}{ll}\text { Bibliography } & 229\end{array}$

$\begin{array}{ll}\text { Index } & 235\end{array}$ 


\section{List of Maps}

1 The Middle East, 1963 xix

2 Cyprus, $1963 \quad$ xx

3 Eurasia and north-east Africa, December $1963 \quad$ xxi

4 The Green Line, Nicosia, December $1963 \quad 69$

5 Turkish Cypriot enclaves, September 1964

6 Cyprus, August $1974 \quad 172$ 


\section{Acknowledgements}

I am very glad to acknowledge, with many thanks, the financial support given me by Britain's Economic and Social Research Council. It enabled me to visit the various far-flung archives and libraries containing material which I needed to consult, and to conduct many interviews.

I welcome this opportunity to thank the staff of the institutions at which I researched, who were patiently and unfailingly helpful. They are, in Britain: the Churchill Archive Centre, Churchill College, Cambridge (the Duncan Sandys papers); Congleton Public Library; Keele University Library; Manchester Public Library; the Public Record Office, Kew, where Evelyn Nugent deserves my special thanks; the Hartley Library, University of Southampton (the Earl Mountbatten of Burma papers); the Library, Trinity College, Cambridge (the R.A. Butler papers); and the United Nations Information Centre Library, London. In Ottawa, Canada: the National Archives, with special thanks to Marey Gregory. In Nicosia, Cyprus: the Archbishop Makarios III Foundation Library; and the Library of the Press and Information Office. In Dublin, Ireland: the Military Archives, with special thanks to Commandant Peter Young; and the National Archives. In the United States: the Lyndon Baines Johnson Library, Austin, Texas, where Regina Greenwell was very helpful; the National Archives of the United States, College Park, Maryland; the United Nations Archives, New York, where Marilla Guptil was exceedingly kind; and the Dag Hammarskjöld Library, United Nations, New York.

For permitting me to consult private papers I am grateful to Duncan Sandys (the papers of Lord Duncan-Sandys), and to Paul Martin Jr (the papers of Paul Martin). Eirwen Harbottle very kindly went to some trouble to ensure that I saw all the relevant papers of her late husband, Brig. Michael Harbottle.

Other assistance, often in identifying sources, was generously given me by many people, whom I thank most warmly. They are: Mark Brady (Canada); the Embassy of Brazil, London; Ian Clark; Capt. Nicholas Catsaras; Richard and Berjoog Day (Cyprus), who were extremely kind; Col. E.A. (Ned) Doyle (Ireland), who was exceptionally helpful; Kenneth E-st, CMG; the Embassy of Finland, London; I.D. Goode (Ministry of Defence), who was most patient; the Press and Information Office of the Government of Cyprus; Sir Vincent Evans, GCMG, MBE, QC; David 
Gordon-Smith; Brig.-Gen. Eddie Heskin (Ireland); Roger and Adele Hill (Canada); John Hilliker (Historical Section, Department of Foreign Affairs and International Trade, Ottawa); Norman Hillmer (Canada); C.M. Hobson (Joint Service Command and Staff College, Bracknell); Col. J.R.L. Howard; Ann Hughes; Chris Hughes (Household Cavalry Museum); Col. Heikki Hult (Finland); Ted Johnson; Dan Keohane; Michael Kennedy (Ireland); Andrew Lawrence, who with much care and patience drew the maps; Brenda Levenson (Foreign and Commonwealth Office); Kristina Lindholm, who kindly summarized a Swedish document; Ann Livingstone; Jean Morin (Directorate of History and Heritage, National Defence Headquarters, Ottawa), who kindly supplied a lot of material; M.D. Sawyer (Army Historical Branch, Ministry of Defence); Ian Soutar (Foreign and Commonwealth Office); Evniki and Spyros Stavrinakis (Cyprus), who were extremely kind; Paul Steenhausen; Tessa Stirling (Cabinet Office); Ambassador Monteagle Stearns (United States); the Embassy of Sweden, London (special thanks to Anna Girvan); Scott C. Taylor (Manuscripts Processor, Lauinger Library, Georgetown University, Washington DC); Richard Thorpe; Ambassador Krister Wahlback (Sweden); and Flt. Lt. Mike Young.

I sought substantive help about the crisis from some individuals who have examined particular aspects of it, and from many who were personally involved in it. A few of the latter pleaded, very reasonably, that age and fading memory left them unable to assist. To my considerable regret, the latter ground was firmly (but charmingly) advanced by Lord Carrington who, as Minister without Portfolio during the crisis, handled a lot of Cyprus business for Britain's Foreign Office. But I was extraordinarily fortunate in that all the others I approached responded with the utmost helpfulness - way beyond what I could reasonably have expected.

My warmest thanks for telephone conversations are therefore due to: Anthony S. Bennell, who was most helpful in other ways, too; Maj. Michael Gilmore; Col. J.N.R. Hallett; Sir Nicholas Henderson, GCMG, KCVO; General Sir Frank Kitson, GBE, KCB, MC, DL; Adonis Kyriakides; Lt. Col. W. Nott (Ireland); General Sir John Waters, KCB, CBE; and Martin Williams, CVO, OBE.

For corresponding with me I thank no less warmly: Lars Ericson (War Archives, Sweden); the late Brig. Michael Harbottle, OBE; Michael Herman; Ambassador Max Jakobson (Finland); K.D. Jamieson; Jarl Kronlund (Finland); Christopher Meynell; Brig. Michael Perrett-Young, who was exceptionally helpful, on the telephone as well as on paper; Sune Persson (Sweden), who went to a lot of trouble; Maj.-Gen. Indar Rikhye (United Nations); Sir Brian Urquhart, KCMG, MBE (United 
Nations); Sir Francis Vallat, GBE, KCMG, QC; Lt.-Gen. Gustaf Welin (Sweden); James H. Wolfe (United States), who also helped with sources; and Humphrey Wynn.

For allowing me to interview them I express my deep gratitude to: Brig.-Gen. E.A.C. (Ned) Amy (Canada), who kindly travelled some distance to see me; Kaya Bekiroglu (Turkish Republic of Northern Cyprus - TRNC); Ayten (Salih) Berkalp (TRNC); Air Vice-Marshal David Brook, CB, CBE; Sir Mervyn Brown, KCMG, OBE; Lady Butler; Ross Campbell (Canada); Field Marshal Lord Carver, GCB, KCB, CB, CBE, DSO, MC with whom I have also had a considerable, and exceedingly valuable, correspondence; Andreas Christolodou (Press and Information Office PIO, Cyprus); President Glafcos Clerides (Republic of Cyprus); Brig.Gen. Vincent Crawford (Ireland); the late Sir William Dale, KCMG; Louis Delvoie (Canada), who also helped with sources; President Rauf Denktash (TRNC); Sir Derek Dodson, KCMG, MC, DL; Richard Dorman, CBE; Esat Fellahoglu (TRNC), who was most kind; Field Marshal Sir Roland Gibbs, GCB, KCB, CBE, DSO, MC, JP; Lord Nicholas Gordon Lennox, KCMG, KCVO; Charles W. McCaskill, Sr (United States), who in addition kindly lent me some material; Maj.-Gen. John Martin (Ireland); Maj.-Gen. Peter Martin, CBE, who was outstandingly helpful in a variety of ways; Arthur Menzies (Canada); Stephen Millar (Canada), who was also exceedingly generous in letting me have his research material; Sir Richard Parsons, KCMG; Bill Peters, CMG, LVO, MBE, who was very kind; Kypros Psyllides (PIO, Cyprus); Brig.-Gen. Patrick Purcell (Ireland); Basil Robinson (Canada), who also helped with sources; Florence (Cooba) Sale; Col. Desmond Travers (Ireland); Sir Robert Wade-Gery, KCMG, KCVO, with whom I have also corresponded; and Bill Young (Canada).

Earlier versions of Chapters 2 and 8 were published in, respectively, The Cyprus Review (Nicosia) (Fall 1998) and International Journal (Toronto) (Autumn 1998). I thank Tim Farmiloe of Macmillan (now Palgrave) for having agreed to this, and the editors of the journals for having accepted the articles on the basis that in their final shapes they would appear in this book.

Above all, however, my thanks are due to my wife, Lorna Lloyd. She was a cheerful, resourceful, and inventive companion on my foreign travels, and helped unstintingly and most valuably in the various archives and libraries I visited. My gratitude for these and so many other things is enormous. It gives me huge pleasure to dedicate the book to her. 


\section{Chronology}

1955

1 April:

1958

6 December: $\quad$ Private meeting at the United Nations headquarters between the foreign ministers of Greece and Turkey.

1959

11 February: Greece and Turkey, meeting in Zurich, Switzerland, reach an agreement on the future of Cyprus - the Zurich Agreement.

19 February: At a conference in London this Agreement is, in an amended form, accepted by Britain, Greece, and Turkey, and by the Greek Cypriot and Turkish Cypriot communities, as the agreed foundation for the final settlement of the problem of Cyprus' - the London Agreement.

1960

16 August: $\quad$ Cyprus becomes independent on the basis of the Zurich and London Agreements.

1963

30 November: $\quad$ President Makarios makes 13 proposals for the amendment of the Cypriot Constitution.

21 December: Outbreak of fighting between Greek and Turkish Cypriots.

25 December: $\quad$ Turkey threatens to intervene.

Britain offers to play a peacekeeping role, together with Greece and Turkey, if so invited by Cyprus.

Cease-fire agreement reached towards the end of the day (but is highly precarious).

26 December: Makarios agrees to the tripartite peacekeeping proposal, and British troops move out of the British Sovereign Base Areas on the island of Cyprus to establish the 'Joint Force'. It is under the command of Maj.-Gen. P.G.F. Young. (The Force proves, however, to be 'Joint' only in theory, as in effect Greece and Turkey play no part in it.)

27 December: British troops begin patrolling.

30 December: $\quad$ Agreement is reached on the line which, in Nicosia, divides the Greek Cypriot and Turkish Cypriot fighters, and on it being occupied and patrolled by British troops. After the colour in which it was originally drawn on the map, it becomes known as 'the Green Line'. 


\section{4}

15 January:

17 January:

23 January:

24 January:

14 February:

15 February:

19 February:

4 March:

12 March:

13 March:

25 March:

27 March:

26 April:

11 May:

4 June:

5 June:

20 June:

1 July:

8 July:

17 July:

5 August:

6 August:

8 August:

9 August:
Opening of the London Conference on Cyprus.

UN Secretary-General, U Thant, appoints Lt.-Gen. P.S. Gyani of India as his Personal Representative in Cyprus.

London Conference on the point of collapse.

Britain begins her efforts to get the peacekeeping role in Cyprus taken over by a Nato-linked force.

Due to Makarios' steady opposition, the idea of a Natolinked force (or some variant of it) is abandoned.

Britain requests an early meeting of the UN Security Council to consider the Cyprus problem.

Maj.-Gen. R.M.P. Carver assumes command of the Joint Force in place of Young.

After much discussion, the Security Council recommends the creation of a UN peacekeeping force, with a life of three months.

Turkey threatens to act in support of the Turkish Cypriots unless Greek Cypriot attacks cease.

Difficulties in securing contributors for the UN Force are overcome.

UN Secretary-General appoints S.S. Tuomioja, of Finland, as UN Mediator in Cyprus.

UN Force (Unficyp) declared to be operational. Its Commander is Lt.-Gen. Gyani of India, with Maj.-Gen. Carver as Deputy Commander.

Serious fighting breaks out in the region of St Hilarion Castle, in the hinterland of Kyrenia.

Three Greek Cypriots killed in Famagusta. In retaliation, many Turkish Cypriots abducted, not to reappear.

UN Secretary-General appoints Galo Plaza, of Ecuador, as his Special Representative in Cyprus.

Turkey prepares to invade Cyprus.

President L.B. Johnson of the United States adresses an extremely strong note to Turkey, which causes her to hold back.

UN Security Council extends the life of Unficyp for a further three months.

At the instigation of the United States, Dean Acheson, the American elder statesman, becomes involved in the mediatory process at about this time.

General K.S. Thimayya of India takes over from Gyani as Commander of Unficyp.

Dangerous incident occurs at Temblos, near Kyrenia.

Heavy exchanges of fire in Nicosia.

Greek Cypriots launch a heavy attack on Turkish Cypriots in the north-western area around Kokkina.

Turkey begins air strikes on the attacking Greek Cypriots.

Greek Cypriots halt their offensive, but establish an economic blockade of Turkish Cypriot villages in the area and elsewhere. 
31 August: $\quad$ Acheson gives up his mediatory efforts at about this time.

9 September: Tuomioja, the UN Mediator, dies.

10 September: Turkey threatens to act in support of the economically beleaguered Turkish Cypriots.

15 September: Makarios lifts the economic blockade on Turkish Cypriot areas.

16 September: Galo Plaza, formerly the UN Secretary-General's Special Representative in Cyprus, appointed as the new UN Mediator.

25 September: UN Security Council extends Unficyp's life for a further three months.

26 October: Nicosia-Kyrenia road reopened under exclusive Unficyp control.

18 December: UN Security Council extends Unficyp's life for a further three months.

1965

30 March:

The Mediator submits his report, which is rejected by Turkey and the Turkish Cypriots.

1967

November: $\quad$ Serious fighting in southern Cyprus.

1974

July:

Turkey invades Cyprus.

August:

Turkey extends her campaign and takes over the northern third of Cyprus.

1983

November: The Turkish Republic of Northern Cyprus is promulgated.

2000 The deadlock continues. 


\section{Leading Personalities}

Unless otherwise indicated, positions are those held during the crisis of 1963-64. In American terminology, the 'Secretary of State' is the foreign minister, and the 'Department of State' the foreign ministry. The 'Under-Secretary of State' is in effect the minister's deputy. In Britain, the 'Secretary of State for ...' is indicative of a ministerial position; but the 'Permanent Under-Secretary of State' is the head official at a ministry.

Acheson, Dean American elder statesman.

Averoff-Tossizza, Evangelos Foreign Minister of Greece in 1958-59.

Ball, George Under-Secretary of State, US Department of State.

Bunche, Ralph Member of the UN Secretariat.

Butler, R.A. (Rab) Britain's Secretary of State for Foreign Affairs.

Caccia, Sir Harold Permanent Under-Secretary at Britain's Foreign Office.

Carver, Major-General Michael Second Commander of the Joint Force, and then Deputy Commander of the UN Force.

Clark, Sir Arthur Britain's High Commissioner to Cyprus until April 1964.

Denktash, Rauf In effect the deputy leader of the Turkish Cypriot community.

Dodson, D.S.L. An official at Britain's Foreign Office.

Douglas-Home, Alec Prime Minister of Britain. In 1958-59, as the Earl of Home, was Secretary of State for Commonwealth Relations.

Grivas, George Leader of EOKA in the late 1950s. In mid-1964 takes command of Greek troops in Cyprus and of the Cypriot National Guard.

Gyani, Lieutenant-General P.S. Personal Representative of the UN Secretary-General in Cyprus, and then first Commander of the UN Force. 
Inonu, Ismet Prime Minister of Turkey.

Johnson, Lyndon Baines President of the United States.

Kutchuk, Fazil The leader of the Turkish Cypriots, and first VicePresident of Cyprus.

Lloyd, Selwyn Britain's Secretary of State for Foreign Affairs in 1958-59.

Macmillan, Harold Prime Minister of Britain in 1958-59.

Makarios III, Archbishop The leader of the Greek Cypriots, and first President of Cyprus.

Papandreou, George Prime Minister of Greece.

Pickard, Cyril An official at Britain's Commonwealth Relations Office, and Acting High Commissioner to Cyprus in the early months of 1964.

Plaza, Galo Special Representative of the UN Secretary-General in Cyprus, and then second UN Mediator.

Rolz-Bennett, José Member of the UN Secretariat.

Rusk, Dean United States Secretary of State.

Sandys, Duncan Britain's Secretary of State for Commonwealth Relations.

Thant, $U$ Secretary-General of the United Nations.

Thimayya, General K.S. Second Commander of the UN Force.

Tuomioja, S.S. First UN Mediator.

Young, Major-General Peter First Commander of the Joint Force.

Zorlu, Fatin Foreign Minister of Turkey in 1958-59. 


\section{Terminology, Sources and Abbreviations}

The collapse of the bicommunal state of Cyprus at the end of 1963 necessarily raised the question of whether the state continued to have a single, legitimate government, or whether its government had legitimately devolved to each of its two component communities. Naturally, the Greek Cypriot majority claimed the former, seeing itself as solely entitled to govern; while the Turkish Cypriot minority, no less understandably, claimed the latter. Early in March 1964 a resolution of the United Nations Security Council referred several times to 'the Government of Cyprus'; the Greek Cypriot leadership had no difficulty in being identified as the entity to which the phrase referred - and hence as the one authorized to speak internationally on behalf of 'the Republic of Cyprus'; and very soon this position received virtually universal acceptance in the outside world. It must therefore be emphasized that the use of the term 'Greek Cypriot' in the later chapters of this book is not meant to carry any legal, moral, or political significance. It is employed simply as a helpful way of designating one side in the ongoing conflict between Cypriots of different ethnic origin.

There is a large body of secondary literature on, or bearing on, the Cyprus problem, my indebtedness to which is indicated, as appropriate, in the endnotes. The full reference for each such source is noted on the first occasion on which it appears in each chapter; any subsequent references in the chapter to that source are given in an abbreviated and cross-referenced form. Chiefly, however, this book is based on archival material, which is similarly noted. When quotations from archives are in the form of reported speech, it has generally not been thought necessary to draw specific attention to that. The documentary sources have been most valuably supplemented by interviews, telephone conversations, and correspondence, usually with people who were involved in the crisis. Those who helped in these ways are, as a rule, not individually identified in endnotes. 
The main archival sources are indicated in endnotes in the following way:

CNA: National Archives of Canada

DSND: the papers of Duncan Sandys (Churchill Archive Centre, Churchill College, Cambridge)

IMA: Military Archives of Ireland

INA: National Archives of Ireland

LBJ: $\quad$ Lyndon Baines Johnson Library

PRO: Public Record Office (Britain)

UNA: Archives of the United Nations

USNA: National Archives of the United States

Other abbreviations used in endnotes, a few of which are also used occasionally in the text, are:

BFC: British Forces in Cyprus

CBFC: Commander of British Forces in Cyprus

CDS: Chief of the Defence Staff (Britain)

COS: Chiefs of Staff (Britain)

CRO: Commonwealth Relations Office (Britain)

CYP: Cyprus

FO: $\quad$ Foreign Office (Britain)

GOC: General Officer Commanding

HMSO: Her Majesty's Stationery Office

LON: London

MoD: Ministry of Defence (Britain)

NEA: Bureau of Near Eastern and South Asian Affairs (United States Department of State)

NY: New York (United Nations Headquarters or national missions accredited thereto)

POL: Political Affairs and Relations (part of the subject area, Political and Defense) (United States National Archives)

SBA: Sovereign Base Area (British)

State: Department of State (United States)

The text also makes reference to:

AKEL: a left-wing Cypriot political party with Communist affiliations enosis: the union of Cyprus with Greece

EOKA: an anti-British guerrilla movement in Cyprus in the late 1950s

Where an abbreviation is employed in the text, the full title together with its abbreviation is given on its first use in each chapter. 


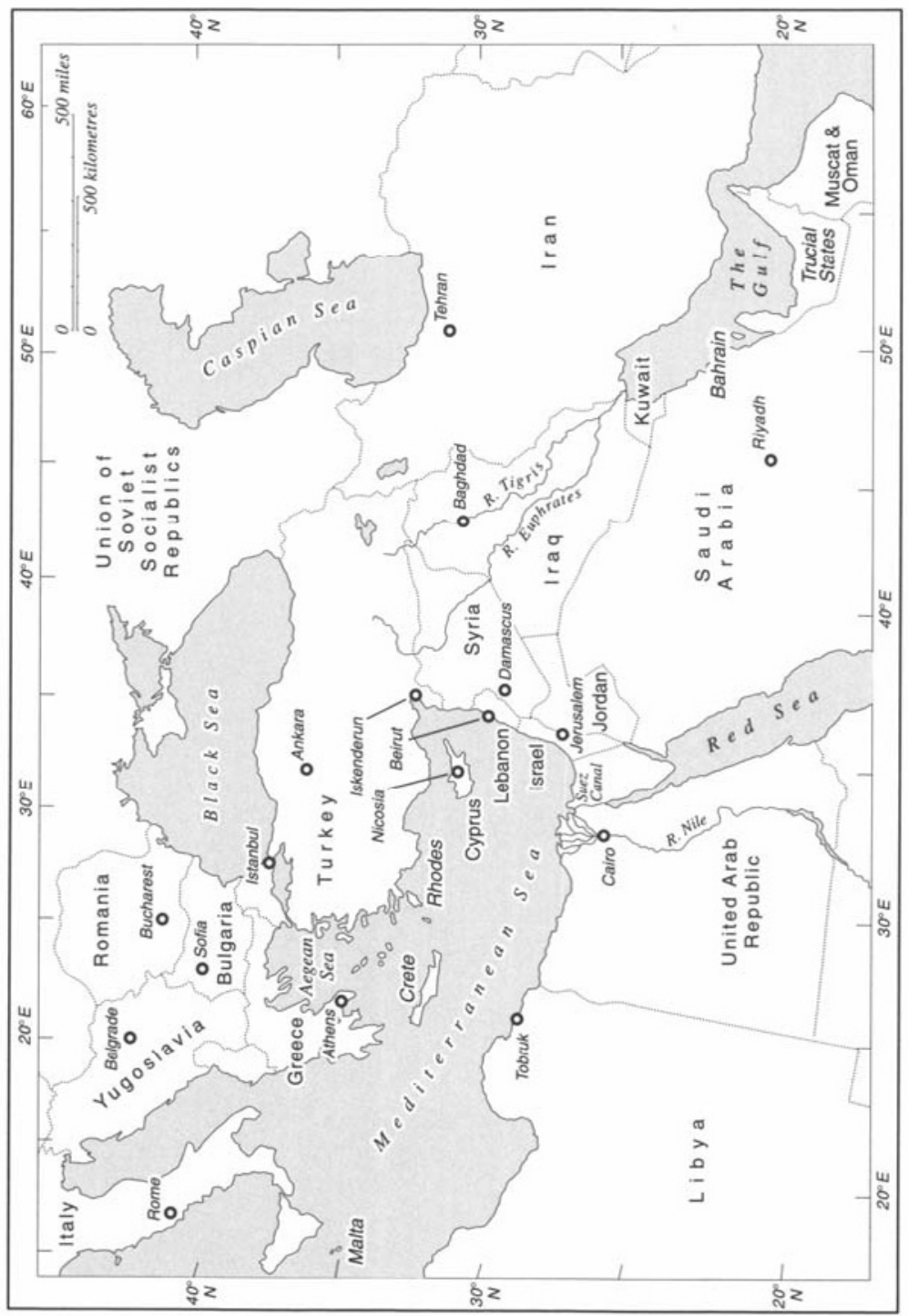

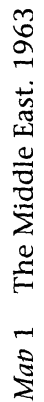


$x x$

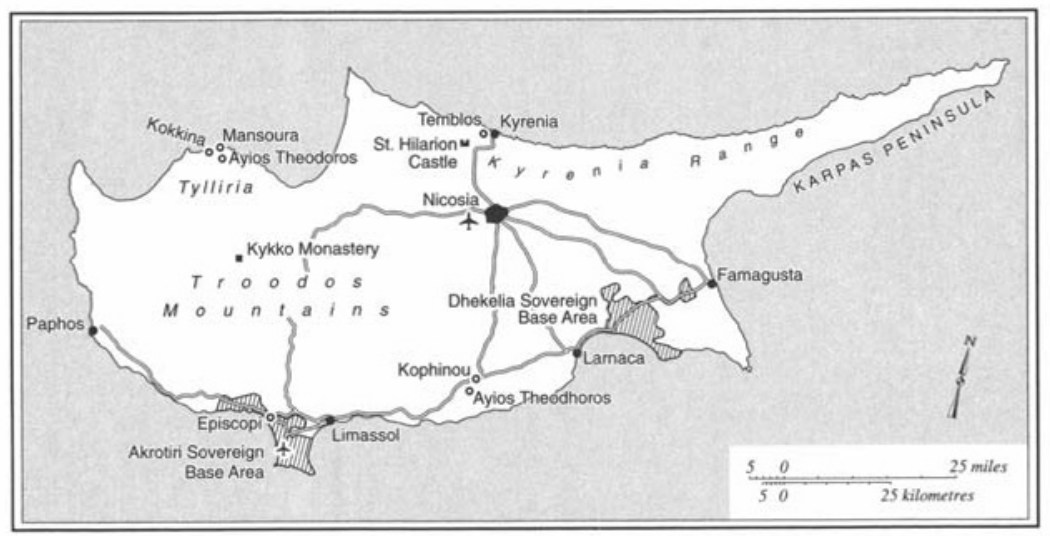

Map 2 Cyprus, 1963 


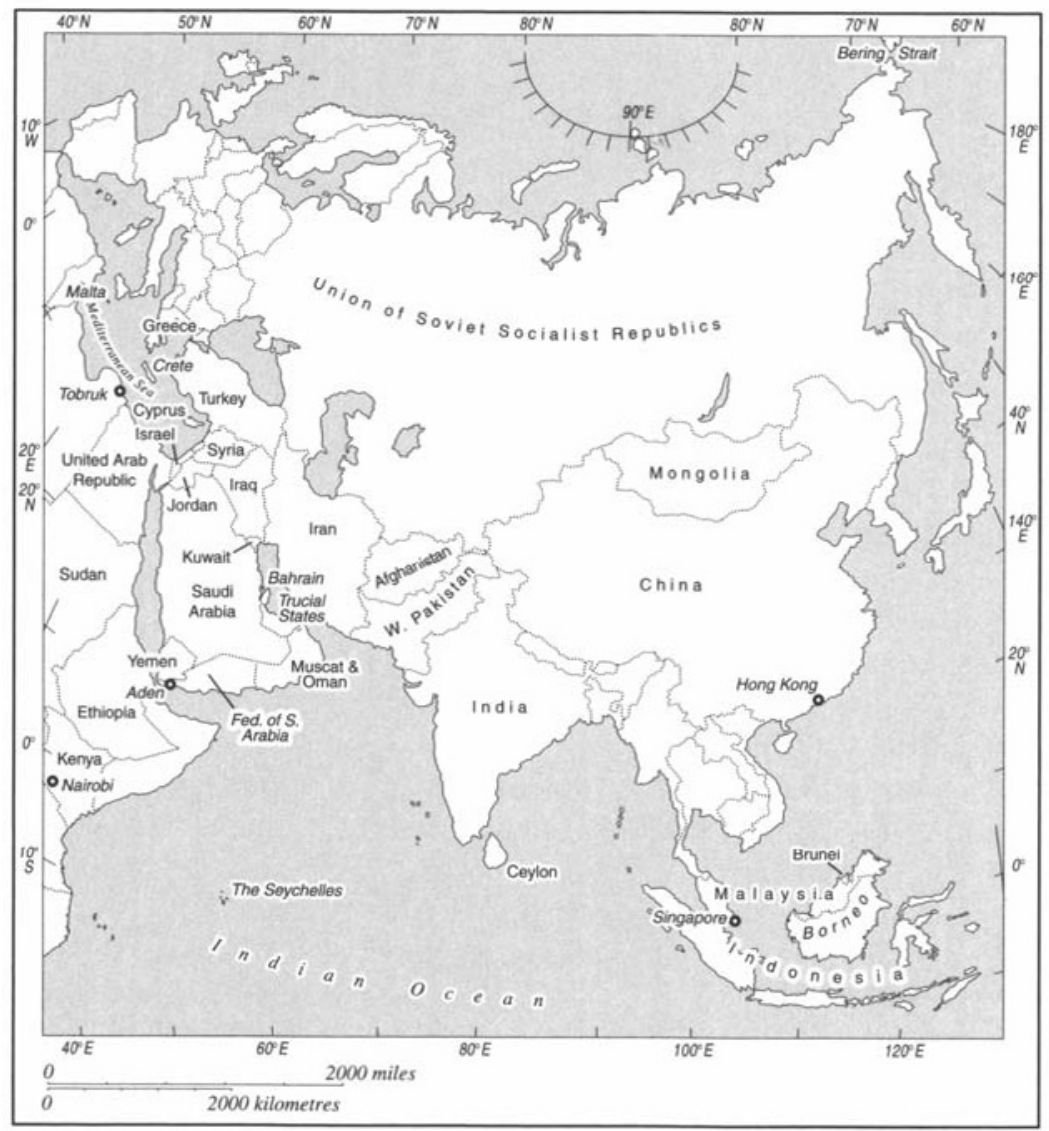

Map 3 Eurasia and north-east Africa, December 1963 